\title{
The polluter Pays Principle and The Law in Cameroon: Too much or too little?
}

Fonja Julius Achu*, Moshefuch Valery Fomchang Ph.D

University of Yaoundé II Department of English Law, Faculty of Laws and Political Science, University of Yaoundé II, BP 1365 Yaoundé

DOI: $10.36348 /$ SIJLCJ.2019.v02i10.006

| Received: 15.10 .2019 | Accepted: 22.10.2019| Published: 30.10.2019

*Corresponding author: Fonja Julius Achu

\section{Abstract}

Since the Rio declaration which held in Brazil in 1992 on the Environment, the draftsmen of the law have often taken recourse to principles when regulating new areas of the law, one of which includes the polluter pays principle. Cameroon has domesticated this principle in its 1996 Environmental management law which is one of the most important principles of international environmental law. The fine imposed on polluters in Cameroon is paltry and therefore cannot really achieve one of the most desired objectives of punishment which is deterrence. The purpose of this paper is to investigate the nature of the liability of the polluter and the quantum of damages imposed on the polluter when he pollutes the environment. The paper is also aimed at investigating whether the principle is an appropriate tool for the liability of polluters under Cameroonian environmental law. In other words the aim is to investigate why the fine levied on polluters is derisory and whether the principle is an effective tool in the compensation of victims of environmental pollution. The paper does so through a reading of records mainly from documentary and Internet search. The data thus collected constitutes the sources from which the law is drawn, stated and analysed in the light of the stated aim of the paper. The results inter alia identify that the polluter pays principle is suppose to be an effective tool in the compensation of victims of environmental pollution but for it to be effective, it must comply to other international law principles such as that of equality, non-discrimination and most importantly the quantum of the damages imposed on the defaulter should be severe enough so as to deter not only the violator from committing the criminal act in future but also to prevent others from following suit. The said results also highlight the limitations and advantages of the polluter pay principle. The results are significant as they expose gaps in the current law in relation to the polluter pays principle and conclude with suggestions on where the law should go.

Keywords: Polluter, Pay, Principle, damages, too much and too little, fine.

Copyright @ 2019: This is an open-access article distributed under the terms of the Creative Commons Attribution license which permits unrestricted use, distribution, and reproduction in any medium for non-commercial use (NonCommercial, or CC-BY-NC) provided the original author and source are credited.

\section{INTRODUCTION}

Environmental resources are not free goods but must be paid for. This is especially important for industries because ultimately industries must make profits for the shareholders. As a basic public good, the environment should at best be taken care of out of public funds. Thus, this ideal situation does not always hold. In a developing country where the meeting of basic budgeting needs out of national revenues is not easily attainable, the idea that conservation needs be met out of the usual public coffers would only be an aspiration rather than an immediately realisable goal meeting conservation needs, required the creation of novel techniques of raising finances. These include; licenses and permits for various activities, fines for infraction of environmental law, environmental bonds and pollution charges. These money raising devices should be seen across the entire spectrum of the system of environmental law. Each device should be employed in an appropriate sector. In the sector of industry, all these devices have relevance and have to be studied closely.

Underlying these approaches is the polluter pays principle. Pollution abatement legislation in many countries establishes principles to be followed. One of such principles is the commonly known polluter pays principle. The polluter pays principle simply means that, on the basis of existing regulations and standards, the cost of pollution prevention and control in a given jurisdiction should be borne by the polluter $\left.{ }^{1}\right]$. In some

\footnotetext{
1 Sands. (2004) Principles of International Environmental Law $2^{\text {nd }}$ Ed Cambridge University Press. P.308
} 
cases, if they are unable to pay, the requirement may be lowered or waived $\left[{ }^{2}\right]$.

\section{What does the polluter pay principle mean?}

It has not been easy to give a clear cut and a generally acclaimed meaning to what the polluter pay principle exactly is. One should however not conclude ignorance of the term but as a manifestation of the complex and flexible nature of the subject. Legal writers on the subject have had to view it from various perspectives. According to Roy Cordato, "the polluter pays principle states that whoever is responsible for damage to the environment should bear the costs associated with it[3]. The term polluter pays principle has been aptly defined in Article 4(u) of the 1996 Law [4] to mean a principle: "according to which, charges resulting from measures aimed at preventing, reducing and fighting against pollution and the rehabilitation of polluted areas shall be borne by the polluter[ []$^{\prime}$ ".

From this definition, it is discerned that, "the polluter pays principle means that the polluter should bear the expenses of carrying out pollution [6]." It is the legal requirement that the cost of pollution should be

\section{${ }^{2}$ Ibid \\ 3 See Roy, E.C. (1997). "Market-Based} Environmentalism and the Free Market: They're Not the same," The Independent Review, Vol. 1, No. 3, p. 371. See also, De Sadeleer, N. (2002), Environmental Principles, From Political Slogan to Legal Rules, $1^{\text {st }}$ ed., Oxford University Press, p. 2, that describe the polluter pays principle as: "an economic principle through which the polluter is required to pay for his pollution." See further Bleeker, A. (2009), "Does the polluter pay? The Polluter pays principle in case law of the European Court of Justice," EEELR, p. 289 in which the author was of the opinion that: "The polluter pays principle is a manifestation of the principle of equity or "fairness" principle... as it holds the polluter accountable for the pollution he has created in order to avoid passing on costs to third parties who did not contribute to the creation of the pollution."

${ }^{4}$ The Environmental Framework Law, 1996, Article 9 (c).

${ }^{5}$ McEldowney and John Sharron(2010) Environmental Law $2^{\text {nd }}$ Ed Conch Press New York . P.205

${ }^{6}$ See, Grossman, MR (2017), "Agriculture and the Polluter Pays Principle: An Introduction," 59 OKLA.L. Rev. I, p.6. See also, Kramer, L (1992) Focus on European Environmental Law, $1^{\text {st }}$ ed. Sweet and Maxwell Publishers, p. 253 in which he considers the polluter pays principle to mean that: "The cost of preventing and eliminating nuisance must in principle be borne by the polluter." borne by the person responsible for causing the pollution. The polluter should repair the damage he has caused either by making actual reparation or paying the necessary monetary compensation to society [7]. Such compensation can be paid either before or after the event. Payment before the event can be in the form of deposit bonds which are tied to environmental performance to be forfeited if performance falls below expected standards. Care must be taken to ensure that the payments are not too high and impose an unnecessary burden on industries. In some countries, systems for a priori payment have been put in place for polluter licenses [8].

Polluter licenses are envisaged to be applicable if the industrialist's activities to be applicable will cause pollution beyond the established standards. A sum equivalent to the cost of the repair of the pollution is required to be paid. The expectation is that such money will be applied by the public authorities to redress the effects of the pollution. Payment after the polluting event may be made after the determination of a court that set standards have been infringed. These payments should again be commensurate with the harm cause and be capable of redressing such harm through restoration and compensation.

The Polluter pays principle has been promoted at national and international levels as it relates closely to the rules of civil law and state liability for environmental damage. The practical implications of the principle are the allocation of economic obligations in relation to environmental damaging activities, particularly with regard to liability, the use of economic instruments and the application of rules relating to competition and subsidy. Examples of specific application of the polluter pays principle include the adjustment of fees or tax payable by hazardous

\footnotetext{
${ }^{7}$ A case law example is the decision of The People $v$ Betrand Brink and Groupement Coop Buns BS/78/04 before the Bamenda Court of First Instance in which the state counsel preferred an eight count charges against the Director of the defending company, Bertrand Van Brink, for the pollution of natural water, air pollution, and failure to rehabilitate degraded sites caused by exploitation of laterite contrary to the 1994 forestry law and the 1996 environmental code. See again, The People (MINEF) v Tame Soumedjong and Sotramilik (Ltd.) CFI/BA/857/02-03 before the Court of First Instance Bamenda in which the defendant, Director of the milk processing company was accused of polluting the natural waters, air pollution, and the treatment of waste in an ecological irrational manner contrary to the 1996 Environmental Code.

8 See the National Environment Statute, 1995 of Uganda, Part VIII.
} 
installations, as is the case in France[9], to cover the cost of exceptional measures taken by public authorities to prevent and control accidental pollution, and charging to the polluter the cost of reasonable pollution control measures taken when an accident occurs particularly to avoid the spread of the damage or limit the release of pollutants, or their ecological effects. Included also are the cost of rehabilitation measures taken to restore the damaged environment.

From the stand point of protecting the environment, it should be understood that provisions for the application of the polluter pays principle are clearly justified by the understanding of the term polluter and the responsibility to pay for pollution which ensues from qualifying a legal person as a polluter. In this context, the considerations which may come to mind relate to how to define pollution and the conditions for determining pollution. Many framework laws of African countries actually define pollution [10]. In that respect, one can refer to the Cameroonian Environmental Management Code of 1996 which stipulates in its Section 4(v) that pollution means: "Any contamination or direct or indirect modification on the environment provoked by any act likely to: -negatively affect a positive use of the environment by man; threaten the health, security and well-being of man, the flora, and fauna, air, the atmosphere, waters, soils and collective and individual goods." However, the same law also defines some other relevant word as follows: "Pollutant" shall be any substance or solid, liquid or gaseous discharge, any waste, odour, heat, sound, vibration, radiation or a combination of these, likely to provoke pollution. Lastly, the term "polluter" shall mean any private individual or corporate body emitting a pollutant which leads to an imbalance in natural environment.

\section{Origin of the principle}

The polluter pays principle existed since the $19^{\text {th }}$ century. It was declared as a policy of the European community since its first Environmental Action Programme in 1972 although it was not introduced into the European Community Treaty until 1987. This principle was set out by the Organisation for Economic Co-operation and Development (OECD) as an economic principle and as the most efficient way of allocating costs of pollution prevention and control measure introduced by the public authorities in member countries. The first international instrument to refer expressly to the polluter pays principle was the 1972

9 Moutonalo, E.G. (1997). In Industries and Enforcement of Environmental Law in Africa, Sponsored by UNEP and UNDP, p. 42.

${ }^{10}$ The Gambian National Environmental Management Act, 1994 defines it in its Section 39 while the National Environmental Statutes, 1995 of Uganda defines it in its Section 22.
OECD Council Recommendation on Guiding Principles concerning the International Economic Aspects of Environmental Policies, which endorsed the polluterpays principle to allocate costs of pollution prevention and control measures to encourage rational use of environmental resources and avoid distortions on international trade and investment[11].

The Rio Declaration includes it in rather abstract terms stating in its Principle 16 that:

National authorities should endeavour to promote the internalisation of environmental costs and the use of economic instruments, taking into consideration the approach that the polluter should, in principle, bear the cost of pollution, with regard to the public interest and without distorting international trade and investment.

Prior to the United Nations Conference on Development (UNCED), the polluter pays requirement was included in different EC documents such as the 1986 Single European Act[12] the 1992 Maastricht Treaty[13] and the Successive programs of Actions on the Environment. The Convention on the Protection of the Marine Environment of the Baltic Sea Area[14] states the principle as an obligatory norm, while the 1992 Helsinki Convention on the Protection and Use of Transboundary Water Courses and International Lakes[15] include it as a guiding principle. On the global level, the International Convention on Oil Pollution Preparedness Response and Cooperation [16] states in its preamble that the polluter pays principle is "a general principle of international environmental law." More recent examples of reference to it are found in the Amendments to the Protocol for the Protection of the Mediterranean Sea against pollution from landbased sources [17] and the Stockholm Convention on Persistent Organic Pollutants [18].

\footnotetext{
${ }^{11}$ OECD Council Recommendation C (72) 128 (1972), 14 ILM 236(1975).
}

${ }^{12}$ Feb. 17, 1986. See generally the provision of Article 130r(2) that stipulates that: "Action by the Community relating to the environment shall be based on the principles that preventive action should be taken, that environmental damage should as a priority be rectified at source, and that the polluter should pay. Environmental protection requirements shall be a component of the community's other policies.

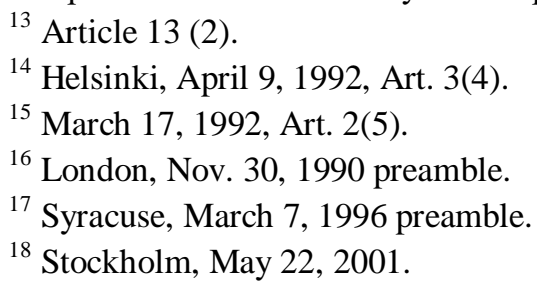

${ }^{14}$ Helsinki, April 9, 1992, Art. 3(4).

${ }^{15}$ March 17, 1992, Art. 2(5).

${ }^{16}$ London, Nov. 30, 1990 preamble.

${ }^{18}$ Stockholm, May 22, 2001. 


\section{Enforcement of the principle}

The enforcement of the polluter pays principle is an important issue which has to be taken care of by all legislation. The traditional forms of enforcement by means of fines and terms of imprisonment may not be sufficient to ensure compliance. Many countries are trying to move away from the command theory of criminal law to the use of economic devices such as incentives and dis-incentives in the form of taxes and charges for behaviours deleterious to the environment and tax, credits, tax exemptions, reward for good environmental performance soft loans and subsidies as incentives. The primary motive behind this approach is to modify behaviour using economic factors rather than legal compulsion. Economic factors are preferred because they have within them an inherent logic towards compliance. This is preferable to reliance on law enforcement officials and litigation in courts which is expensive and does not necessarily promote a conservation ethic within the industrial sector.

Beyond the traditional form of sanctions (punishments for offences) and the emerging concern with economic incentives and dis-incentives, another trend is developing in the drive to ensure enforcement. Environmental consideration have been key factors in the development of legal requirements for the registration, labelling, control on advertising, and classification of dangerous processes, products and byproducts such as hazardous chemicals and waste. To ensure that these requirements are met, the law requires reports on potentially dangerous inputs, products, processes, and by products and provides for inspection and analysis of inputs, products and by products. These techniques have been used particularly in specific legislation relating to hazardous substances and wastes, and they are pertinent to sustainable industrial development as well. Examples of these approaches may be found in the recent laws enacted in Uganda, Malawi, Zambia and Ghana [19].

\section{The aim of the polluter pays principle}

The Polluter pays principle is intended to encourage rational use of scarce environmental resources and to avoid distortions in international trade and investment. It is aim at acting as a deterrent to people and industries which pollute the environment. It is equally aim as acting as retribution for defaulters of environmental law. The aim of punishment is to deter and equally retribute the defaulter of law. In this case, we are talking of environmental damage. It is impossible to lock up a company because it is a moral person [20]. So often, what the law prescribe is the

\footnotetext{
${ }^{19}$ See Pages 38 of UNDP and UNEP.

${ }^{20}$ See Fomchang, M. V. (2019) "The Protection of the Rights To Health Under Cameroonian Law: A Critical Analysis," Unpublished Ph.D. thesis of the University of Yaoundé II Soa, p. 368, in which he is of the opinion
}

payment of a fine [21] which is often in cash even though there are some administrative sanctions such as the closure of the establishment [22]. In the case where the defaulter is a physical person, a fine or imprisonment is often applied. In some cases, both are applied with the same aim namely retribution and deterrence. The question that deserves an answer is: Is this aim of punishment achieved by the polluter pays principle? This question will be answered in the later part of this paper.

\section{The scope of the polluter pays principle}

The polluter pays principle is a basic principle in the framework of the pollution control strategies at national and international levels. According to the principle as interpreted by many governments and decisions-makers, polluters must pay: firstly, the cost of pollution abatement; the cost of environmental rehabilitation and the compensation costs for victims of damages if any, due to pollution. The scope of the polluter pays principle can be understood through the range of compensation mechanisms to victims of environmental damage in the framework, and on the basis of environmental liability. These include a range of components or elements to be considered on the application of the principle such as the nature of conceptual problems encountered in incorporating these elements or components into the legal system. However, the primary goal of the polluter pays principle is to achieve and maintain a cleaner environment.

The polluter pays principle is particularly valid for giving appropriate remedies to victims of damage from environmentally harmful activities. The law presumes that the permission to carry on an activity is conditional on the enterprise absorbing the cost of any pollution arising from the activity. However, other questions arise concerning the consideration of the extent of environmental damage, the need for a reasonable and better compensation for such damage, and the adoption of preventive approaches for better management of environmental resources. The scope of the polluter pays principle depends on the policy-

that, "since the coming into force of the Cameroonian Revised Penal Code of $12^{\text {th }}$ July 2017, corporate criminal liability is now recognized."

${ }^{21}$ See Section 18-1 of the Penal Code that requires that: "Corporate bodies should be sanctioned with the following principal penalties: dissolution, temporary or final closure and fine for any violation against the law of the State that caused harm on another."

${ }^{22}$ Ibid, Section 25-3 of the PC advocated for the closure of an establishment as a CCL against a legal person when it provides that, "the penalty of closure of an establishment shall mean the temporary or final closure of an establishment considered to be a corporate body." 
making context, as it involves many approaches underlying environmental planning (also incorporated in environmental legislation). It is a mechanism for compensation for damage, taking into account its preventive effects.

The polluter-pays principle can be understood within the jurisprudential context. The jurisprudence integrates all the conceptual categories and different goals of strict environmental liability and restitution for environmental damage in order to ensure that an enterprise which is engaged in a hazardous or inherently dangerous industry which poses a potential threat to the health and safety of the working person in the premises and those residing in the surrounding areas owes an absolute and non-delegable duty to the community to compensate for such harm.

The scope of the polluter pays principle can also be understood within the economic context as the approaches involved, promote the integration of the costs of environmental degradation. In this regard, Principle 16 of the Rio Declaration states that: "National authorities should endeavour to promote the internationalisation of environmental costs and the use of economic instruments, taking into account the approach that the polluter should in principle bear the cost of pollution, with due regard to the public interest and without distorting international trade and investment."

\section{Towards the promotion of the polluter pays principle}

Legal and administrative responsibilities for pollution control usually rests with national authorities who are charged with enforcement of national legislation and standards as established. As mentioned above, at the national level, the polluter-pays-principle is introduced as an obligation for states to promote the development of attitudes that prevent environmental pollution and other environmental damage through national legislation which incorporates the internationalisation of externalities. However, the polluter-pays-principle does not have as much support as other principles of the same nature of general application. Its further development has often run into objections. It should be stated that, the increased attention paid to the polluter pays principle is a consequence of the consideration given to the relationship between environmental protection and economic development, and of the recent efforts to use economic instruments in environmental law and policy.
Indeed, the 1990 Ministerial Declaration of the Second World Climate Conference [23] illustrates the need for a new regulatory approach which promotes the use of economic incentives or instruments and integration of pollution prevention. It states that "... Appropriate economic instruments may offer the potential for achieving environmental improvements in a cost-efficient manner."

As with many other principles, there is, at present, no compensation and authoritative definition of the polluter pays principle. The polluter pays principle is among the strategies in the legal and administrative field which was identified as significant in the future of international environmental law, particularly in the framework of the Montevideo programme on the Development and Periodic Review of Environmental Law. As a general principle, it is considered as applicable to the formation and development of environmental law during the present decade. The polluter pays principle is also an extension which is actually used in international declarations, including the Rio Declaration [ 24 ]. Through Principle 22, the Stockholm Declaration [25] also underpins the polluter pays principle. However, in none of these declarations is the principle comprehensively defined, although many documents of a legal nature describe what the principle is intended to mean in the context of the subject matter concern.

European community law also reaffirms the polluter-pays-principle which establishes environmental liability with regards to the prevention and remedying of environmental damage. It provides that: "community policy on the environment shall be based on the principles that the polluter should pay [26]." Another recommendation of the European Community also imposes the application of the polluter-pays-principles. It states that:

Natural and legal persons governed by public or private law who are

${ }^{23}$ The Second Climate Conference was held on 29 October to 7 November 1990 in Geneva. It should be noted that, the World Climate Conferences are a series of international meetings organized by the World Meteorological Organization about global climate issues.

${ }^{24}$ Principle 7.

${ }^{25}$ That requires that: "States shall take all possible steps to prevent pollution of the seas by substances that are liable to create hazards to human health, to harm living resources and marine life, to damage amenities or to interfere with other legitimate uses of the sea."

${ }^{26}$ See Article 15, Directive 2008/98/12/EC on the Revised Directive of Waste Framework Directive of 12 of December 2008. 
responsible for pollution must pay the cost of such measures as are necessary to eliminates that pollution or to reduce it so as to comply with the standards or equivalent measures laid down by this public authority [27].

The polluter pays principle is also considered in certain international conventions such as the Convention on the Law of the Sea [28].

At the national level, a variety of framework laws of many African countries actually contain provisions relating to the polluter pays principle. A case in point is Section 39 of the National Environmental Management Act of Gambia which stipulates that:

(1) No person shall pollute the environment in excess to any standard. (2) A person who pollutes or permits any other person to pollute the environment in excess of any standard... commits an offence. (3) In addition to any sentence That may be imposed upon a polluter... the court shall require such person (a) To pay the full cost of cleaning up the environment and of removing the effects of the pollution or (b) Clean up the environment and remove the effects of the pollution (4)... the court may also require the polluter to meet the costs of the pollution to third parties through compensation, restoration or restitution [29]".

The polluter pays principle is also contained in the Cape Verde's Order of 1993[30] which defines the principle as "a responsibility of agents for the consequences to third parties for their direct and indirect actions on natural resources, whereby the polluter is obliged, at his cost, to correct or rehabilitate

${ }^{27}$ See for example the United Nations Convention of the Law of the Sea (UNCLOS), of 16 November 1973, Article 145(1)(a) on the protection of the Marine Environment that requires that, the States should adopt appropriate rules and relating to the: "prevention, reduction and control of pollution and other hazards to the marine environment, including the coastline, and of interference with the ecological balance of the marine environment, particular attention being paid to the need of protection from harmful effects of such activities ad drilling, dredging, excavation, disposal of waste, construction and operation or maintenance of installation, pipelines and other devices related to such activities."

28 Particularly in the framework of Section 9 on responsibility and liability, Article 235.

${ }^{29}$ Act No. 13 of 1994, Article 39(1) to (4).

${ }^{30}$ See to this effect Order No. 86/IV/93 of 26 June 1993, Article 3 Para. 1. the environment, and prevented from continuing the polluting action." The Environmental Management Act of Malawi which was promulgated on the $3^{\text {rd }}$ of August 1996 also states in its Section 43(3) that, the Minister may: “...Prescribe such fees as he shall deem necessary for the monitoring, clean up, removing or disposing of pollutants discharged or emitted into the environment."

\section{Other policy alternatives to the polluter pays principle}

There are several policy approaches to environmental pollution control. The first approach is direct regulation and control. Here, the government can decide what each polluter must do to reduce pollution by setting certain uniform standards and subjecting violators to legal penalties. But according to many policy-makers, and to experience, this approach is not fair when one considers the conditions in which each polluter operates. It is not efficient either because effluents and damage also differ.

The second approach is the fixing of charges for various levels of pollution, in order that, the user bear the cost of pollution prevention and control measures. Economists prefer this approach as well as the polluter pays principle because they believe that pollution results from a failure of the pricing system and that the best way to correct the failure is through the system itself.

The third category of such approaches involves the enforcement of torts and property rights through the judiciary. Indeed, under torts, a pollution victim can seek redress in court for damage suffered. The method is effective when the identity of the affected party is known, but the assignable damage might be ambiguous on many cases. Under property rights, the government creates and gives rights either to the polluters who then have rights to discharge pollutants into the environment or its components, or to the potential victims who then have rights to preclude anyone from discharging effluents. The fourth approach is one consisting of substantial subsidy for individual treatment. However, the implementation of these strategies requires much information on technology of each industry to enable regulation. Polluters also respond differently to these approaches in their own interest. Some find it cheaper for example to pay a pollution tax, while others might reduce pollution or avoid charges by using different raw materials or resorting to improved energy consumption.

\section{Environmental liability and the polluter pays principle}

Environmental liability is a legal concept whereby damage to the environment can be determined, assessed and redressed through the rule of law. Environmental legislation creates obligations which give rise to liability for environmental damage, including pollution and nuisances and the consequences of irrational use of environmental resources or 
technologies. The effectiveness of the polluter pays principle as a judicial mechanism applied to the protection of the environment depends on the ability of the liable party to pay the cost of compensation, as well as on the available alternatives. As a major component of environmental liability, the polluter pays principle include the mechanism by which responsibilities are engage in the context of the rights and obligations provided by laws.

Under traditional jurisprudence, civil liability is a mechanism of compensation based on the existence of damage. This means that unless damage has occurred, there is no liability. In the area of environmental law, liability can be based either on negligence, that is on fault, or on the degree of nuisance. The prerequisite for strict liability are: (1) Damage to property or a person and (2) Causality between damage and an action or activity.

Another condition would be that the legal rule should provide that the action from which the damage derived is prohibited or controlled, that the citizens have had notice of the legal rule prohibiting or controlling such an action, and are aware of the possible consequences of non-compliance with the rule. In other words, liability based on negligence requires proof that the environmental damage was foreseeable, that the party whose action or activity caused the damage had a legal duty of care to prevent the damage and that he failed in that duty. Therefore the effectiveness in solving environmental problems remains a particular concern. Many conventions provide supervisory mechanisms to ensure compliance [ 31 ]. Other conventions contain provisions relating to state responsibility. However, such responsibility is absolute and states cannot evoke reasons such as lack of time or capacity to fulfil their obligations.

\section{The problem of the polluter pays principle}

The difficulty surrounding the polluter pays principle is two-fold. First, in order to make the polluter pay, it must first be ascertained when it is appropriate to

31 As regards conventions without enforcement mechanisms, see Candice, S. (1994) "Interpreting the Polluter Pays Principle in the Trade and Environment Context." Cornell International Law Journal: vol. 27: Iss. 3, Article 5, p. 587 who was of the opinion that: "most of the major international environmental agreements- such as the Montreal Protocol on Substances that Deplete the Ozone Layer, the Convention on International Trade in Endangered Species of Wild Fauna and Flora, and the Basel Convention on Transboundary Movements of Hazardous Wastes and their Disposition do not contained either enforcement mechanisms or dispute settlement mechanisms." regard him as a polluter. For example, where car causes pollution, is the polluter the manufacturer of the car, the producer of the fuel, or the driver of the car? Secondly, if the principle is to be applied fairly, it must be ascertained to what extent the polluter has degraded the environment, and the extent of that degradation must then be given a precise monetary value. However, there is authority to the view that, the polluter is taken to mean the producer of the waste or pollution leading to the undesired damage.

A case in point is the decision of Paul Van de Walle and Others $v$ Texaco Belgium SA [32] in which, during renovation of a building in Brussels, it was found that water saturated by hydrocarbons was leaking in from the adjacent Texaco service station. The leakage was attributable to deficient storage facilities in the service station. The owner of the premises and Texaco had a commercial lease which covered the service station but the station was operated by a manager under an operating agreement. On trial evidence clashed as to whether the contaminated soil could be seen as waste and also whether Texaco could be considered as the producer of the said waste. The court decided that, the unexcavated contaminated soil could be regarded as waste and that Texaco could be seen as the producer of the waste. It is submitted here that; the polluter is the producer of the damage.

Originally, recommended by the OECD in May 1972, the principle is still highly controversial, particularly in developing countries where the burden of internationalizing environmental costs is perceived as being too high partly because of its role in harmonizing standard. The principle provides important guidance for formulating domestic environmental laws and policies. For example, under Principle 10 of the Rio Declaration, "National authorities should endeavour to promote the internalization of environmental costs and the use of economic instruments, taking into account the approach that the polluter should, in principle, bear the cost of pollution, with due regard to the public interest and without distorting international trade and environment."

To reach a better allocation of resources in line with paragraph 2 of the guiding Principle, it is desirable that the private cost of goods and services should reflect the relative scarcity of environmental resources used in their production. If this is the case, consumers and producers would adjust themselves to the total social cost for the goods and services they are buying and selling. The polluter pays principle is a means of moving towards this end. From the point of view of conformity with the polluter pays principle, it does not matter whether the polluter passes on to his prices some or all of the environmental costs or absorbs them.

\footnotetext{
${ }^{32}$ Case C-1/03, Paul Van de Walle and Others $v$ Texaco Belgium SA, ECR (2004) I-07613.
} 


\section{The application of the principle in Cameroon}

It has been the aim of this paper to argue that, polluters should be held liable for pollution cause to the environment. The application of the polluter pays principle into the Cameroonian legal system can be principally discerned through national law and case law [33]. In Cameroon, the polluter pays principle is spelt out in Article 9 (c) of the 1996 Environmental Framework Law that requires that, the pollute and pay principle refers to: "charges resulting from measures aimed at preventing, reducing and fighting against pollution and the rehabilitation of polluted areas shall be borne by the polluter." It performs three crucial rules namely to prevent, to reduce, to fight against pollution and in cases were the violation of environmental law leads to the degradation of the environment, the rehabilitation of the damage cause by the polluter.

Section 4 (v) of the Cameroonian Environmental Management Code of 1996 spells out the nature of acts that may pollute the environment. This Section stipulates that: "Any contamination direct or indirect modification on the environment provoked by any act likely to: -negatively affect a positive use of the environment by man; -threaten the health, security and well-being of man, the flora, and fauna, air, the atmosphere, waters, soils and collective and individual goods." From the above, it is evident that nuisance prevention and cost should be borne by the polluter for either directly or indirectly affecting the environment. This paper argues that although the polluters pays principle warrants that polluters should bear the costs or held liable for damage caused to the environment, the fine levied on the defaulter in Cameroon seems to be too paltry (small) and this may not deter the polluter or defaulter from committing or repeating the same offences. Again, it should be stated that, this principle as applied in Cameroon underpins most of the regulations of pollution affecting land, water or air by harmful or potentially harmful substances.

Thus, in CCO $v$ MINEF[ 34 ] Complexe Comestique de l'Quest, (CCO), a soap factory located in Bamoungoum Quarter in Bafoussam, was accused of

\footnotetext{
${ }^{33}$ On the role of case law on the understanding of the polluter pays principle, see Lindout, P.E. and Van de Broek, B. (2014). "The Polluter Principles: Guidelines for Cost Recovery and Burden Sharing in the Case Law of the European Court of Justice," Utrecht Law Review, p. 49 that was of the opinion that: "case law has provided markers with regards to, for instance, the necessity of a causal connection between activities and pollution, who can be considered a polluter, and possibilities to differentiate contributions from categories of polluters."

${ }^{34}$ Matter No. 004/PVI/MINEF/DPEF/Spe 15/01/02. (Unreported).
}

polluting the air because of a poisonous gas it produced from its pipes contrary to Section 21 of the 1996 Code. The question raised before the court was whether the contaminated gas produced from the pipe could be seen as an air pollutant and whether $\mathrm{CCO}$ could be considered as the producer of the pollutant. In other words, what pollution was under consideration? The then Ministry of the Environment and Forestry (MINEF)[35] concluded that the contamination of the air by poisonous gas could be regarded as air pollution. The then Ministry asked the defaulter to pay the sum of one million (1,000,000 FRS) Francs as penalty for violating the environmental law. This judgment shows that the courts are willing to apply the polluter pays principle in Cameroon. Again, the judgment seems to suggest that, the actor with the main responsibility under the polluter pays principle is the producer of the pollutant, in this case, the manager of CCO. Fonja, J [36] argues that the judgment of the court was correctly judged in this instance but frown that the amount levied by the court was too small as compared to the damage caused to the society. The argument made by Fonja, J that the sum was too paltry (small) is sound and valid given that, the quantum of damages must be weight against the proportionality of the damage caused by the pollution. This leads to the conclusion that to enforce observance to the polluter pays principle, the penalties against environmental offences should be very severe [37].

Another evidence to illustrate the paltry nature of the quantum of damages granted by the courts of Cameroon under the polluter pays principle can be seen

\footnotetext{
${ }^{35}$ Then, Ministry of Environment and Forestry but today Ministry of Environment, Nature Protection and Sustainable Development.

${ }^{36}$ Fonja, A.J. (2005). "Legal and Policy Mechanisms for Urban Pollution Control with Particular Reference to Selected Cities in Cameroon," Unpublished Ph.D. Thesis of the Faculty of Law and Political Science of the University of Yaoundé II, Soa, p. 115.

${ }^{37}$ Fine should be server enough (ranging up to half a billion) to deter repetition and continuation of environmental offences. See for example the provision of Section 80 of Law No. 96/12 of $5^{\text {th }}$ August 1996 relating to Environmental Management in Cameroon (the Environmental Code), that punishes "any person who dumps dangerous waste on Cameroonian territory with life imprisonment and fine of from 50 million to 500 million." See further, Section 57 of Law 2003/006 of 21 April 2003 to Lay down regulations governing modern biotechnology in Cameroon (the Biosafety Law) attracts severe punishments ranging up to 7 years imprisonment or 100 million francs CFA.
} 
in the decision of the case of UCB $v$ MINEF [38] in which the same ministry levied a penalty of five million $(5,000,000 \mathrm{frs})$ Francs as stated by Section 82 of the Code on a brewery company, Union des Brasseries du Cameroun located in Douala for polluting the air. The amount was later tripled to fifteen million $(15,000,000$ FRS) Francs when the company refused to stop polluting the air. The case before the court was to determine whether the fuel oil they dumped on the soil could be considered a pollutant. According to the Ministry, Union des Brasseries du Cameroun was to be held liable for their actions.

Regarding the question of which the polluter is, in this case, just as in CCO, the Ministry based the channelling of responsibility to the producer. This implies that, liability under the polluter pays principle should be channel to the producer of the waste. However, Esoe $\left[{ }^{39}\right.$ ] like Fonja [40] argues that the application of liability on them runs contrary to the principle of equality given that, $\mathrm{CCO}$ was levied the payment of a million while in the present case, Union des Brasseries was fined the sum of $15,000,000 \mathrm{frs}$. Thus, she argues that, there is supposed to be a fixed amount as discrimination is unhealthy for it creates an atmosphere of uncertainty. Again, it may hinder the punishment from achieving its most desired aim which is deterrence that is, the ability to discourage repetition. It is believe that a very high penalty will achieve this aim for no company will afford to lose a huge amount of money because of polluting the air which can be checked.

In equally another case, the weakness that in Cameroon, the quantum of damages levied on the polluter when implementing the polluter pays principle is derisory can be illustrated in the decision of the case of KETCH $v$ MINEP[41]. On the facts of this case, $\mathrm{KETCH}$ was accused of exploiting a quarry without carrying out the requisite environmental impact assessment [42]. The end result was the production of an enormous quantity of dust which polluted the air. $\mathrm{KETCH}$ was then slammed a penalty of five million (5,000,000 FRS) Francs as punishment in accordance with Section 79 of the Environmental Code. Again, the main criticism advanced against the decision is the quantum of damages levied against the defender. As the sum of five million is seen as too small an amount to

\footnotetext{
38 Matter No. 0/65/MINEF/SG/Spe/DNIE/PEIE/C4. (Unreported).

${ }^{39}$ Esoe J.M (2015 “The Legal Mechanisms for Waste Management in Cameroon: The Case of Yaoundé and Douala”. Unpublished Master's Theses of the University of Yaoundé II. P. 70

${ }^{40}$ See Fonja, A.J. op. cit. p. 120.

${ }^{41}$ Case No. 0016/PV/MINEP/DPEF/SPE of $20^{\text {th }}$ June 2004. (Unreported).
}

deter a big company like the defendant from committing or repeating the same offence.

In the matter of M. NGUENTA Mesmine $v$ MINEF [42] the defendant, Mr. NGUENTA owned a garage in the Bastos neighbourhood in Yaoundé. Pieces of metals and scraps of old vehicles were dumped in the surrounding causing land pollution. The air was also polluted because of the smoke and gas given off when weldering was done. The offence was aggravated because Bastos is a high class residential area. The defendant was accused of violating Section 21 of the Code and therefore was levied a fine of 2,500,000 FRS. $\mathrm{He}$ was also instructed to move the garage from that neighbourhood.

Lastly, in the case of HEVECAM $v$ MINEF [43], the defendant was accused of emitting strong odours containing ammonia into the air. Other odours were also emitted during the spraying of its palms against pests. This act violated the Law. The defendant was asked to pay damages amounting to five million $(5,000,000$ FRS) Francs according to Section 82 of the Code. From the decisions of this case, it is easy to reach the conclusion that even though odour pollution cannot be avoided, it is equally punishable. It is submitted that, this decision highlights the fact that, "the emission of noise and odours likely to be harmful to human health, excessively inconveniencing the neighbour and endanger the environment shall be prohibited [44].” But again, the amount of the fine levied on the company is too small not only to deter a big company like the defendant from continuing with the offence but equally from deterring other companies from polluting the atmosphere.

An issue which cannot go uncommented on is the question of determining whether the courts will sanction just any form of pollution under the polluter pays principle? This paper follows the position of Wandiga, S [45] who argues that, if all industries are told to stop air pollution entirely, then all such industries will close down because they cannot function or operate without producing smoke. For this is like asking a person to cut a pound of flesh without spilling blood. A solution has been provided by Section 23 of the Code, which enshrines that:

\footnotetext{
${ }^{42}$ Matter No. 07/PVI/MINEF/DPFE/SPE of May 2002. (Unreported).

43 Matter No. 004/PVI/MINEF/DPFE/SU/SPE of 15/01/02. (Unreported).

${ }^{44}$ See Article 60(1) of the Environmental Code.

${ }^{45}$ Wandiga, S.O. (1996) "Impact of Industries on the Environment" a paper presented at a forum on Industries and Enforcement of Environmental Law in African Industries Expert Review Environmental Practice, sponsored by UNDP, p. 20.
} 
When persons responsible for discharging pollutants into the atmosphere beyond the norms laid down by the administration do not respect regulations, the competent administration shall issue them a notice to pay in this light.

An interpretation of this section reveals that a certain level of pollution is tolerated. It is only when this threshold has been exceeded that a penalty is imposed on the defaulter. Even with this, another problem is posed which is that, what the tolerated level of pollution is. There is no equipment yet in Cameroon to measure the tolerable level. It is submitted here that, this equipment should be acquired for it will enable polluters to know the threshold level of tolerable pollution.

\section{CONCLUSION}

From what has been canvassed in the foregoing it is discerned that the quantum of damages or fine levied on polluters of the environment is too paltry to deter polluters from polluting the environment. The argument put forward is that if the amount levied on polluters is high it will lead to the winding up of many companies in Cameroon since many are not financially strong. This argument is not tenable because it makes no sense that the environment should be polluted because our industries should remain in business. What should be done is that companies should be told to use raw materials that are less polluting. The consequence of pollution is one of the causes of climate change. It is noted that climate change is one of the biggest problem mankind is facing today. We noted that liability for non-observance of the obligations imposed by environmental provisions represents rather a complex issue. The non-observance of environmental law provisions brings about civil or criminal liability that involve specific sanctions determined by law, including imprisonment, financial compensation and rehabilitation of the degraded environment in the framework of the polluter pays principle. Taking into cognisance the problems of the application of the polluter pays principle discussed above the following recommendations have been put forward.

The polluter pays principle should incorporate the principle of proportionality, as well as the principle of non-discrimination in the allocation of damages. Given that it is hard to establish the exact amount of waste created by a polluter, there is therefore, the need for a cost allocation-based model of damages in which the cost of waste will be calculated based on the area of the property and nature of the waste.

It is proposed that the polluter pays principle should guide the courts in implementing the law and to do this a polluter for the purpose of the polluter pays principle may be construed to mean the seller of the fuel, the producer, the negligent truck agent that transported the fuel from one town to another and whose negligence cause damage to the environment, in as much as it may refer to the house owner who uses the fuel and whose actions infringes the environmental law and cause a tort to another through the commission of pollution, nuisance, odour or noise in the air, land, sea in the community in which they find themselves. To this effect, the judicial authorities in Cameroon who have the duty of rightly interpreting and applying the law should based their decision on the facts of each case, give an appropriate consideration in its interpretation and application of the term "polluter" whenever need arises. This would go along way to lead to the adequate compensation of the damage caused by these environmental law violators against others.

Finally, it is recommended that the quantum of the damages should be proportional to the wrong committed by the polluter. That is, that the polluter pays principle should cover pollution prevention and control measures, liability and clean-up cost for environmental damage, to this effect, the amount of damages should not be too paltry an amount but must be huge enough so as to deter the emission of gas or the pollution to the environment by either the same company or individual or third party in the future. 